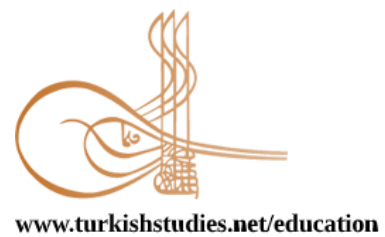

Turkish Studies - Educational Sciences

eISSN: 2667-5609

ResearchArticle / Araștırma Makalesi

\title{
Çok Dilli Bir Sınıfta Dik Temel Harflerle Okuma Yazma Öğretimi: Bir Durum Çalışması *
}

\author{
TeachingLiteracyWithVertical Basic LettersIn A MultilingualClassroom: A Case Study
}

\author{
Nurhüda Sözen ${ }^{* *}$
}

\begin{abstract}
Reading is a skill for the childto be acquired and developed in primary school. However, it is known that there are many students in our country who have difficulty in gain ingth is skill. These difficulties may arise from different reason such as bilingualism and learning difficulties. Especially in some parts of our country there are children whose immigrant and mother tongue is different. These children have difficulty in reading and learning difficulties because their mother tongue is different. Before they start school, they speak the language they have learned from their families and environment. When they start their education life, they meet Turkish, the language of instruction. These children become bilingual children in the process. Since they do not know Turkish sufficiently, their vocabulary is not developed sufficiently. The processes of learning to read and write are negatively affected and make them feel academically inadequate. This research aims to describe how literacy teaching is carried out in a multilingual classroom. The study was carried out with the students of 1-J branch of Cumhuriyet Primary School in Güngören district of İstanbul in 2017-2018 academic year. The study was designed as a case study, one of the qualitative research approaches, and the data was collected through a Personal Information Form, unstructured observations and reflective diary. It was found that students had difficulty in writing the letters e, a and y mostly during the literacy teaching process. It was concluded that the literacy books prepared by the state are not sufficient in terms of quality and quantity. Especially the students whose mother tongue is different and found to be immigrants had difficulty in adapting to the school culture. It was determined that the problems of comprehending the open syllable were over come by the rhythm repetitions. In particular, it was concluded that reading open syllables with rhythm facilitates comprehension. It was found that the students who did not receive pre-school education generally could not place the letter size on the line specified on the page surface and had difficulty in writing the letters at the specified height and width. It was found that the most difficult letters for students to comprehend were " $y, \mathrm{p}, \breve{\mathrm{g}}$ ”. During the writing process, the students had difficulty in writing the letters "e, $\mathrm{a}, \mathrm{y}$ ". These students had problems in positioning the queues of the letters and they didn't complete the writing. It was also found that they could not position the letters in the appropriate form. It was determined that the literacy books prepared by the state were not sufficient, and it was suggested that they should be better equipped with higher quality drawings, more concrete words, more appropriate figure sand more a esthetically prepared visual figures. It was determined that the students who migrated due to lack of Turkish language skills had difficulty in under standing what they read. In conclusion, it can be suggested that nonlinguistic leiter intelligence test can be applied with the cooperation of psychological counsel or and Arabic
\end{abstract}

\footnotetext{
* Bu çalışma16-20 Ekim 2019 tarihlerinde Antalya'da düzenlenen 18. "Uluslararası Sınıf Öğretmenliği Sempozyumu"nda sözlü bildiri olarak sunulmuştur.

** Dr., Öğretmen, Milli Eğitim Bakanlığı, Temel Eğitim Bölümü

Dr. Teacher, Ministry of Education, Primary Education

ORCID 0000-0003-2937-472X

nurhudasozen@hotmail.com

Cite as/ Atıf:Sözen, N.(2020). Çok dilli bir sınıfta dik temel harflerle okuma yazma öğretimi: bir durum çalışması.TurkishStudies-Education, 15(3), 2047-2062. https://dx.doi.org/10.29228/TurkishStudies.41926

Received/Geliş: 25 February/Şubat 2020

Accepted/Kabul: 21 June/Haziran 2020

Checkedbyplagiarism software

Copyright (C) INTACLTD, Turkey

Published/Yayın: 25 June/Haziran 2020

CC BY-NC 4.0
} 
teacher in order to determine learning difficulties in some immigrants. In order to improve language skills in the preschool period, children from 3 years of age who are immigrants who do not speak our language can be provided with gradual pre school education. Workshops on peer bullying for students, creative drama activities for parents can be done and adaptation problems can be eliminated and cultural integration can be achieved.

Structured Abstract: Introduction: Reading is a skill for the child to be acquired and developed in primary school. However, it is known that there are many students in our country who have difficulty in gaining this skill. These difficulties may arise from different reasons such as bilingualism and learning difficulties. Especially in some parts of our country there are children whose immigrant and mother tongue is different. These children have difficulty in reading and learning difficulties because their mother tongue is different. Before they start school, they speak the language they have learned from their families and environment. When they start their education life, they meet Turkish, the language of instruction. These children become bilingual children in the process. Since they do not know Turkish sufficiently, their vocabulary is not developed sufficiently. The processes of learning to read and write are negatively affected and make them feel academically inadequate. There is a lot of research to carry out the process of teaching literacy through entertaining activities and for immigrant students to develop a positive attitude towards reading (Cin, 2018; Dorman, 2014; Gultutan, 2019; Aykırı, 2017)

\section{Purpose of theResearch}

This research aims to describe how literacy teaching is carried out in a multilingual classroom. Based on the experiences of the teacher, who works in a classroom of children whose mother tongue is different, the aim of this research is to describe the first literacy with orthogonal basic letters. Answers to some of these questions were sought. In the first literacy teaching stage;

- How is the preparation and adaptation phase?

- What is the voice and syllable teaching stage?

- How is the word and sentence teaching phase?

- It is important throughout the literacy teaching process.

- What are the material requirements?

- What are the parents' reasons?

- What are the problems of your system?

- What are the students' needs?

The findings to be obtained as a result of the research;

- It will bring some reason to give a more realistic perspective that will teach reading and writing with steep basic letters,

- It will create an environment for thinking, discussion and new research on the process of teaching literacy to children whose mother tongue is different,

- It emphasizes the fact that children in multilingual languages in the literacy teaching program regulate the missing aspects of the existing program.

\section{Working Group}

The study was carried out with the students of 1-J branch of Cumhuriyet Primary School in Güngören district of İstanbul in 2017-2018 academic year.

\section{Method}

The study was designed as a case study, one of the qualitative research approaches, and the data was collected through a Personal Information Form, unstructured observations and reflective diary. 


\section{Findings and Discussion}

It was found that students had difficulty in writing the letters e, a and y mostly during the literacy teaching process. It was concluded that the literacy books prepared by the state are not sufficient in terms of quality and quantity. Especially the students whose mother tongue is different and found to be immigrants had difficulty in adapting to the school culture. It was determined that the problems of comprehending the open syllable were overcome by the rhythm repetitions. In particular, it was concluded that reading open syllables with rhythm facilitates comprehension. It was found that the students who did not receive preschool education generally could not place the letter size on the line specified on the page surface and had difficulty in writing the letters at the specified height and width. It was found that the most difficult letters for students to comprehend were "y, p, $\breve{g}$ ". During the writing process, the students had difficulty in writing the letters "e, a, y". These students had problems in positioning the queues of the letters and they didn't complete the writing. It was also found that they could not position the letters in the appropriate form. It was determined that the literacy books prepared by the state were not sufficient, and it was suggested that they should be better equipped with higher quality drawings, more concrete words, more appropriate figures and more aesthetically prepared visual figures. It was determined that the students who migrated due to lack of Turkish language skills had difficulty in understanding what they read.

\section{Conclusion and Suggestions}

As a result of the researchStudents who could not pay enough attention to the letter-sound relationship read different words similar to the written word during their reading (such as a guest instead of a host),

-It is observed that the words, which are composed of three letters with middle syllables, swallowing the last letter of the middle syllables. (garlic-garlic, Erzincan-Erzican, ... etc.)

Students whose attention period is not long enough and having a problem of focusing read the first sentences of the text correctly and the next sentences with errors.

-When reading multi-syllable words, hesitation, boredom and inability to read were observed. (for example, being able to read each syllable that constitutes the word "Kastamonu" but having difficulty reading the whole word, forgetting the first syllables until the last syllable, exhibiting boredom behaviors as it cannot concentrate attention in this cyclical process)

Reading errors such as thinking to code the words in the mind due to the mother tongue difference in the students coming from the immigrant language, adding sound or sound combinations to the head of the word in this intellectual process (pencil-adding, İskenderun-êî́skenderun) were encountered.

In conclusion, it can be suggested that non-linguistic leiter intelligence test can be applied with the cooperation of psychological counselor and Arabic teacher in order to determine learning difficulties in some immigrants.

In order to improve language skills in the preschool period, children from 3 years of age who are immigrants who do not speak our language can be provided with gradual preschool education. Workshops on peer bullying for students, creative drama activities for parents can be done and adaptation problems can be eliminated and cultural integration can be achieved.

Kewords: Primariy Education, Multilingual classes, Literacy Teaching, İmmigrant Students, Syrian Students

Öz: Okuma çocuk için ilkokulda kazanılması ve geliştirilmesi gereken bir beceri olmasına rağmen ülkemizde bu beceriyi kazanmada zorluk yaşayan birçok öğrencinin olduğu bilinmektedir. Bu güçlükler; iki dillilik, öğrenme güçlükleri gibi farklı nedenlerden kaynaklanabilmektedir. Özellikle ülkemizin bazı bölgelerinde ana dili farklı olan ve göçle gelen çocuklar vardır. Bu çocuklar ana dilleri farklı olduğu için okuma güçlüğü ve buna bağlı olarak öğrenme güçlüğü yaşamaktadırlar. Okula başlamadan önce ailelerinden ve çevrelerinden öğrendikleri dili konuşurlar. Eğitim hayatına başlayınca da öğretim dili olan Türkçe ile tanışırlar. Dünyalarına farklı bir dil giren çocuklar süreç içerisinde iki dilli çocuklara dönüşürler. Türkçe'yi yeterli düzeyde bilmedikleri için sözcük dağarcıkları yeterince gelişmemiştir. Okuma-yazmayı öğrenme süreçleri bu durumdan olumsuz etkilenmekte ve akademik olarak kendilerini yetersiz hissetmelerine neden olmaktadır. $\mathrm{Bu}$ araştırma çok dilli bir sınıfta okuma-yazma öğretiminin nasıl gerçekleştirildiğini betimlemeyi 
amaçlamıştır Çalışma 2017-2018 Eğitim - Öğretim yılında İstanbul ili Güngören ilçesi Cumhuriyet ilkokulu 1-J şubesi öğrencileri ile gerçekleştirilmiştir. Nitel araştırma yaklaşımlarından durum çalışması olarak tasarlanan araştırmada veriler kişisel Bilgi Formu, yapılandırılmamış gözlemler ve yansıtıcı günlük aracılığıyla toplanmıştır. Öğrencilerin okuma yazma öğretim süreci boyunca en çok e, a ve y harflerini yazarken zorlandıkları tespit edilmiştir. Özellikle ana dili farklı olan ve göçle geldiği tespit edilen öğrenciler okul kültürüne uyum sağlamakta zorlanmışlardır. Ritimle yapılan tekrarlarla öğrencilerin açık heceyi kavrama sorunlarının aşıldığı tespit edilmiştir. Özellikle açık heceleri ritimle okumanın kavramayı kolaylaştırdığı sonucuna ulaşılmıştır. Okul öncesi eğitim almamış öğrencilerin genel olarak harfin boyutunu sayfa yüzeyinde belirlenen satıra yerleştiremedikleri, harfleri belirlenen yükseklik ve genişlikte yazma konusunda zorlandıkları tespit edilmiştir. Öğrencilerin kavramakta en çok zorlandıkları harflerin "y, p, ğ" olduğu tespit edilmiştir. Yazma sürecinde ise en çok e, a, y harflerini yazmakta zorlandıkları harflerin kuyruklarını konumlandırmada sorun yaşadıkları, yarım bıraktıkları ve uygun formda konumlandıramadıkları tespit edilmiştir. Devlet tarafından hazırlanan okuma-yazma öğreniyorum kitaplarının yeterli olmadığ1 belirlenmiş, daha kaliteli çizimlerle, daha somut kelimelerle, kelimelere daha uygun olan ve daha estetik hazırlanan görsel figürlerle kısacası nitelik ve nicelik olarak daha donanımlı hazırlanması önerilmiştir. Türkçe dil becerilerinde ki yetersizlikten dolayı göçle gelen öğrencilerin okuduklarını anlamada zorlandıkları belirlenmiştir. Sonuç olarak göçle gelen bazı öğrencilerdeki öğrenme güçlüklerini tespit etmeye yönelik olarak dile dayalı olmayan leiterzeka testinin psikolojik danışman ve Arapça öğretmeninin işbirliği ile uygulanabileceği önerilebilir. Okul öncesi dönemde dil becerilerini geliştirmek için 3 yaşından itibaren her dönem arttırılan ders saatleri ile göçle gelen ve dilimizi bilmeyen çocukların aşamalı olarak okul öncesi eğitim almaları sağlanabilir. Öğrencilere yönelik akran zorbalığı ile ilgili atölye çalışmaları, velilere yönelik yaratıcı drama faaliyetleri gerçekleştirilerek uyum sorunları giderilebilir ve kültürel kaynaşma sağlanabilir.

Anahtar Kelimeler: Sınıf Öğretmenliği, Çok Dilli Sınıflar, Okuma Yazma Öğretimi, Göçle Gelen Öğrenciler

\section{Giriş}

Okuma; yazılı sembollerin göz ile algılanması, eş zamanlı olarak zihinde organize edilmesi ve yapılandırılması ile oluşan düşünsel süreç olarak ifade edilebilir. Yazma, anlatılmak istenenleri, semboller aracılığıla ve alfabetik ilişkiler kurarak ifade etme becerisidir. Öğrencilerin okumayazma becerisini gerçekleştirebilmesi için sesleri tanıması ve ses bileşimlerini çözümleyip anlamlandırması ve yazılı sembollerle ifade etmesi gerekmektedir. Bu beceriyi kazanan öğrenciler için süreç okuduğunu anlama çalışmalarıyla devam etmektedir. Anlama; zihnin görme, işitme veya dokunma ile algıladığı bilgiler üzerinde düşünme işlemidir. Bilgilerin diğer bilgilerle organize olarak yeniden yapılanması sürecine ise düşünme diyebiliriz. Bireylerin okuduklarını eksiksiz anlaması ve mantıklı düşünmesi, anladıklarını ön bilgileriyle doğru yapılandırması ile gerçekleşir. Okuma becerisi, ses farkındalığ 1 ve alfabetik sembolleri keşfederek birleştirme becerisine bağlı olarak oluşurken kelime tanıma hızı ve kelime hazinesinin zenginliği ile gelişir. İlkokulun ilk yılında öğretmen rehberliğinde kazandırılan bu beceri sıkıcı ve tekdüze olmamalıdır. Okuma, öğrenilmesi gereken bir görev olarak değil, ilgi duyulan, merak uyandıran ve zevk alarak kazanılan bir beceri haline getirilmedir. Dolayısıyla okuma-yazma öğretim süreci eğlenceli etkinliklerle yürütülmeli ve öğrencilerin okumaya karşı olumlu tutum geliştirmeleri sağlanmalıdır. Bu araştırmanın genel amacı anadili farklı olan çocuklardan oluşan bir sınıfta görev yapan öğretmeninin deneyimlerinden yola çıkarak dik temel harflerle, ilk okuma yazma sürecini betimlemektir. $\mathrm{Bu}$ amaç doğrultusunda aşağıdaki sorulara yanıt aranmıştır. İlk okuma yazma öğretim sürecinin;

- Hazırlık ve uyum aşaması nasıldır?

- Ses ve hece öğretimi aşaması nasıldır?

- Kelime ve cümle öğretimi aşaması nasıldır?

- Okuma-yazma öğretim süreci boyunca yaşanan sorunlar nelerdir?

- Materyal kaynaklı sorunlar nelerdir?

- Veli kaynaklı sorunlar nelerdir?

Turkish Studies -Education, 15(3) 
- Sistem kaynaklı sorunlar nelerdir?

- Öğrenci kaynaklı sorunlar nelerdir?

Araştırma, 2017-2018 eğitim öğretim yılında, 25.09.2017 - 08.06.2018 tarihleri arasında İstanbul ili Güngören ilçesinde sosyoekonomik olarak dezavantajlı çevrede bulunan bir ilkokulda gerçekleştirilmiştir. Araştırma sonucu elde edilecek bulguların;

- Dik temel harflerle okuma yazma öğretecek öğretmenlere daha gerçekçi bir bakış açısı kazandırmak için bazı tavsiyeler getireceği,

- Ana dili farklı olan çocuklara okuma yazma öğretim süreci üzerinde düşünme, tartışma ve yeni araştırma ortamı yaratacağı,

- Okuma yazma öğretimi programında çok dilli çocuklar gerçeğini vurgulayarak var olan programın eksik yönlerinin düzenlenmesine katkı sağlayacağ 1 ve var olan eğitim programının geliştirilmesine ışık tutacağı düşünülmektedir.

\section{Yöntem}

Araştırmada, nitel yaklaşımlardan biri olan durum çalışması uygulanmıştır. Durum çalışmalarında bir ya da daha çok olay, ortam, program, sosyal grup, toplum ya da diğer sınırlandırılmış bir sistemin derinlemesine analizi yapılır. Durum bir öğretmen, öğrenci, müdür, program, olabileceği gibi bir sınıf, okul, topluluk, gibi bir grup ya da belirli bir politika, kural ya da tutum olabilir (McMillian, 2004: 271) Araştırmanın çalışma grubunu, İstanbul ili Güngören Cumhuriyet İlkokulu'nun 1-J şubesi öğrencileri oluşturmuştur.Veriler;

- Öğrencilerle ilgili akademik gelişim, Türkçe dil gelişimi ve sosyal uyum ile ilgili verilerin yer aldığ kişisel bilgi formu,

- Yapılandırılmamış gözlemler,

- Okuma-yazma öğretimi ile materyaller (sesli kitaplar, ders kitapları, etkinlik örnekleri, fişler) ve

- Araştırmacı öğretmen tarafindan yaşanan süreci betimleyen yansitıcı günlük aracıllğıyla toplanmıştır. Toplanan veriler betimsel analiz yöntemiyle analiz edilmiştir.

\section{Bulgular}

\section{Dik Temel Harflerle Okuma-Yazma Öğretim Sürecinin Hazırlık ve Uyum Așamasına İlişskin Bulgular}

Hazırlık aşaması incelendiğinde, öğrencilerin bir kısmının sürece hazır olduğu, sürece hazır olmayan öğrencilerin, okul öncesi eğitim almadığı dolayısıyla okul ve sınıf kurallarını kavramakta zorlandığ1 görülmüştür. Okul öncesi eğitim almayan öğrencilerin kalem tutma, makas kullanma ve kes yapıştır görevlerinde akranlarına göre daha çok zorlandığı gözlenmiştir. Bazı öğrencilerin kalemi doğru tutarken bazılarının yanlış tuttuğu, kalemi fazla bastırdığı tespit edilmiştir. Ayrıca sol elini kullanan öğrencilerin defter ile arasındaki açıyı tam ayarlayamadığ 1 için sorun yaşadığı belirlenmiştir.

Hazırlık aşamasında başarılı olamayan öğrencilerin bazılarının göçle geldikleri tespit edilmiştir. Türkçe dil becerilerinin yetersiz olmasından dolayı göçle gelen öğrenciler, verilen yönergelere uygun davranmakta zorlanmışlardır. Bunun yanı sıra bazı öğrencilerin el kaslarının gelişmemiş olmasından dolayı etkinlikler, tam olarak amacına ulaşamamıştır. Sınıfta göçle gelen öğrencilerin dil bilmediği, kendini ifade edemediği, beslenme saatinde yemek kurallarına uygun olmayan davranıșlar sergiledikleri, okul kültürüne uyum sağlamakta zorlandıkları ve 1 . Sınıfa hazır olmadıkları gözlenmiştir. Çocuklara birbirlerinin dillerini bilmeseler bile birlikte yaşama kültürünü kazandırmak için serbest etkinlik saatlerinde bazı aktiviteler yapılmıştır. Örneğin göçle gelen öğrenciler Türk öğrencilerle eşleştirilmiştir. Daha sonra her iki öğrencinin yan yana oturmas1 sağlanmış ve sıranın üzerine sadece bir hikâye kitabı bırakılmıştır. Hikâye kitabının bol resimli olmasına özen gösterilmiştir. İki öğrencinin hikâye kitabının kapağını, görsellerini inceleyerek 
kitap hakkında sohbet etmelerine yönelik çalışmalar yapılmıştır. Türk öğrencilere resimlerde gördüklerini ayrıntılı olarak göçle gelen arkadaşlarına anlatmaları istenmiştir. Teneffüs aralarında sınıftaki veya koridordaki nesnelerin Türkçe karşılıklarını göçle gelen öğrencilere öğretmeye yönelik akran işbirliği çalışmaları yapılmıştır. Göçle gelen öğrencilerin okulun ilk birkaç haftasında sınıftaki nesnelerin adlarını Türkçe olarak öğrenmeleri ve konuşabilmeleri, okul algılarını olumlu yönde etkilemiştir. Yine bir diğer çalışmada her iki öğrencinin sınıfta asılı olan harf kartlarının yanına giderek harfi temsil eden nesne hakkında konuşmaları daha sonra harfi okumaları ve seslendirmeleri istenmiştir. Göçle gelen öğrencilerin Türk öğrencilerle kaynaşmasını sağlamak, Türkçe dil becerilerini geliştirmek ve kendi uyruğundan olan öğrencilerle çeteleşmesini engellemek için gün boyunca teneffüslerini geçireceği arkadaşları öğretmen tarafından belirlenmiştir. Okuma yazma öğretim süreci boyunca gerçekleştirilen bu tür etkinliklerin Türkçe dil becerilerinin kazandırılmasında, kültürel uyumlarında ve sosyalleşmelerinde etkili olduğu tespit edilmiştir.

\section{İlişkin Bulgular}

Dik Temel Harflerle Okuma-yazma Öğretim Sürecinde Seslerin Öğrenme Aşamasına

Dik temel yazı ile okuma yazma öğretim sürecinin seslerin öğrenme aşamasına ilişkin bulgular incelendiğinde harfler, düz, yan, yuvarlak gibi sade ve basit çizgiler içermesinden dolayı harflerin yazımında herhangi bir sorun yaşanmamıştır. Sesleri öğrenme aşamasına ilişkin bulgular; "sesi tanıma", "sesi ayırt etme" ve "sesi yazma" olmak üzere üç tema altında incelenmiştir.

Sesi Tanıma: $\mathrm{Bu}$ aşamada öncelikle öğrencilere sesi fark ettirmek için çeşitli etkinlikler yaptırılmıştır. Örneğin "e" sesini fark ettirmek için kartondan yapılmış bebekler öğrencilere verilmiştir. Sınıfla birlikte "eee, eee, ee" şeklinde vurgu yaparak ninni söylenmiştir. Daha sonra masaya isminde "e" harfinin geçtiği birkaç nesne konmuş ve nesnelerin hangilerinde "e" sesinin bulunduğu sorulmuştur. Daha sonra aile üyelerinin (anne, baba, abla, abi, kardeş, anneanne, dede, babaanne, amca, hala, dayı, teyze...vb.) isimlerini düşünmeleri istenmiştir. Kimlerin isimlerinde "e" sesinin geçtiği buldurulmaya çalışılmıştır. Sınıfta sessiz kalan öğrencilerle sohbet edilmiş, meyve ve hayvan görselleri gösterilerek hangilerinde "e" sesinin bulunduğu sorulmuştur. Bu süreçte öğrencilerin sesleri karıştırdığı, unuttuğu görülmüştür. Öğrencilerin okula hazır olmadan okula başlamaları ve dikkat sorunları sıklıkla gözlenmiştir.

Sesi Ayırt Etme: Bu aşamada öğrencilere ayırt edilmesi planlanan sesin geçtiği kelimeler verilmiştir. Verilen kelimelerde öğrencilerin sesin başta, ortada ve sonda bulunabileceğini fark etmeleri hedeflenmiştir. Örneğin "l” sesinin ayırt etme ile ilgili yapılan etkinlik aşağıda gösterildiği gibidir:

Öğretmen: "l" sesinin geçtiği üç nesne ismi bulalım mı? Hadi biraz düşünelim. Bulanlar parmak kaldirsin.

Ayşe: Öğretmenim kalllem (1 harfime vurgu yaparak)

Öğretmen: Çok güzel (Bu esnada tahtaya kalem resmi çizer. Altına kalem yazar ve 1 harfini pembe tebeşir ile yazarak vurgu yapar.) evet parmakları göreyim. Düşündügünüz yanlış bile olsa söyleyebilirsiniz. Sizi dinliyorum.

Ahmet: Öğretmenim dolap

Ali: Öğretmenim limon

Öğretmen: Çok güzel limon (Tahtaya sarı tebeşirle limon resmi çizilir. Altına limon yazılır ve 1

harfini sarı tebeşir ile yazarak harfin kelimenin başında olduğu vurgulanır.)

Selin: Silgi

Şule: Elbise

Ayşe: Öğretmenim cetvel 
Öğretmen: Çok güzel cetvel (Tahtaya tebeşirle cetvel resmi çizilir. Altına cetvel yazılır ve 1 harfini turuncu tebeşir ile yazarak harfin kelimenin sonunda olduğu vurgulanır.)

Birinci grup harflerin öğretim etkinlikleri esnasında öğrencilerin bir kısmı sesi tek başına görünce tanıyabilmişlerdir. Aynı sesi kelimenin içinde duyunca ayırt etmekte zorlanmışlardır. Bu durum fonolojik farkındalık düzeylerinin yetersizliği olarak ifade edilebilir. Ancak 3. grup harflerin öğretiminde öğrencilerin geneli sürece alışmış sesleri kelimelerin içinde duyunca da ayırt edebilmişlerdir.

Sesi Yazma: $\mathrm{Bu}$ aşamada öncelikle verilen sesin geçtiği nesneler tekrar ettirilmiştir. Örneğin "a" sesinin yazım aşamasında öncelikle havada yazma ve sıranın üzerine yazma çalışmaları yapılmıştır. Daha sonra "a" sesini noktalar halinde çizilmiş ve görseli yerleştirilmiş olan "a" harfinin üzerinden giderek çizmeleri istenmiştir. Çizme çalışması esnasında öğrencilerin oturma pozisyonları, duruşları ve kalem tutuşları ögretmen tarafından kontrol edilmiştir. Çizgi çalışması bittikten sonra etkinlik kalın kuru boyayla boyanmıştır. Yapılan etkinliğin bir örneği aşağıda gösterildiği gibidir.

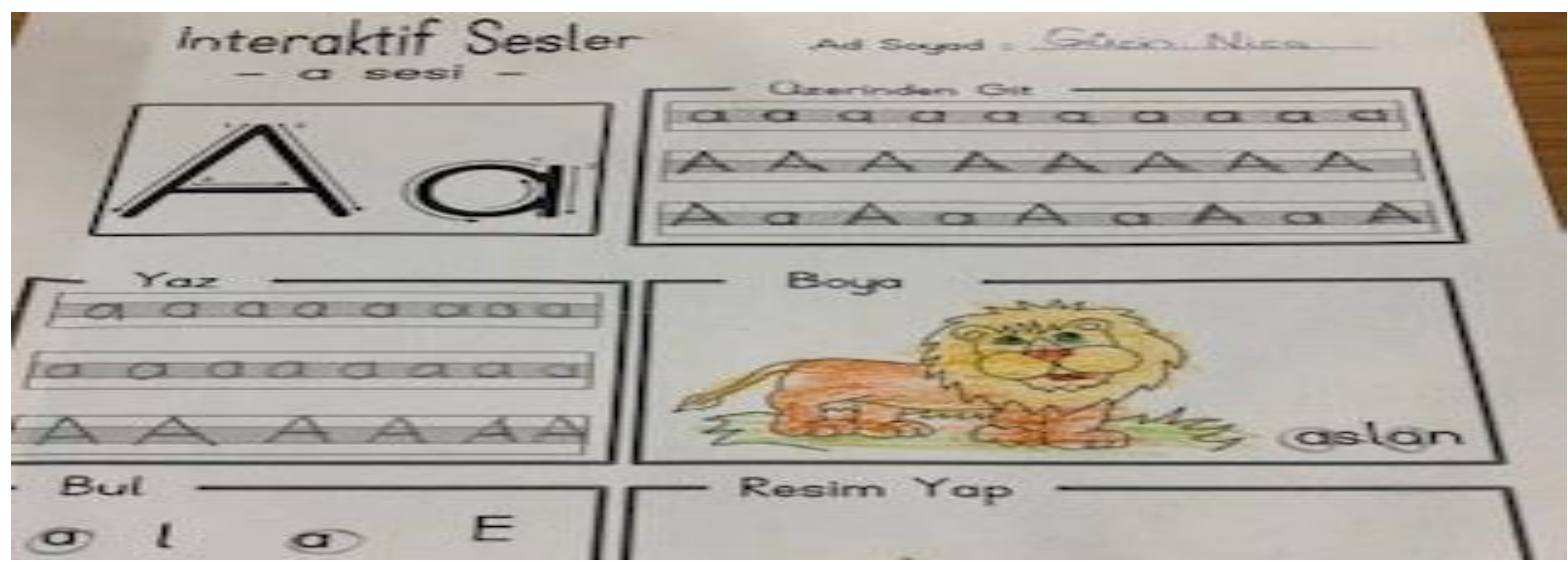

Harfi okuma ve yazma sürecinde sesi tanıtacak bir görsel aracıllı̆ıyla harflerin büyük ve küçük yazılışları ile ilgili bilgi vermiştir. Tahtaya, öğrencilerin defterine uygun olacak şekilde kılavuz çizgileri uygun boyutta çizmiştir. Daha sonra öğrencilerin harfleri taşırmadan yazabilmelerini sağlamak amacıyla birkaç kez model olarak yazılmıştır. Sınıftaki öğrenciler 3'erli gruplarla tahtaya kaldırılmıştır. Her öğrencinin doğru hareketlerle yazıncaya kadar seslendirerek yazmaları istenmiştir. Bu esnada yazmak istemeyen öğrencilerden biri ve öğretmen arasında gerçekleşen diyalog şöyledir:

Öğretmen: Hadi Miraç yazalım.

Miraç: Ben yazmayı sevmiyorum. Çok sıkııı bir iş.

Öğretmen: Peki beni seviyor musun?

Miraç: Evet seviyorum.

Öğretmen: O zaman bana yardım et. Ben çok yoruldum. Şimdi sen tebeşiri tut. Ben seni yönlendireyim. Böylece birlikte yazmış oluruz.

Miraç: Kaç kez yazacağız.

Öğretmen: Harfi taşırmazsak sadece iki kez

Miraç: Tamam olur.

Öğretmen: “y”nin kafası ikinci aralıkta, kuyruğu aşağıda olacak. Üstteki iki ucu yukarıdaki kırmızı çizgiye değmeli, alttaki ucu son çizgiye değecek. Dikkatle incele, önce ben yapıyorum. 
Miraç: Tamam anladım.

Öğretmen: Hadi bunu birlikte yapalım.

Miraç: Aslında ben yapabilirim.

Öğretmen: Ne renk tebeşir istiyorsun.

Miraç: Turuncu.

Öğretmen: Al bakalım (Tebeşiri vererek)

Miraç: Nas1l oldu öğretmenim.

Öğretmen: Harika, şimdi aynısını sırandaki fotokopiye yapmanı istiyorum. İlk satır bittikten sonra parmak kaldır gelip kontrol edeceğim. Çok güzel yazacağına eminim.Bu süreçte öğretmen öğrencilere, harfi çizgiye doğru konumlandırmaları, taşırmamaları ve doğru hareketlerle yazmalarını sağlamak için model olmuş ve yapılan çalışmaları sıklıkla kontrol etmiştir. Dağıtılan fotokopilerde ara ara harfin başlangıç yerlerine kırmızı noktalar konulmuştur. Harfi doğru hareketlerle yazmaları için kırmızı noktalardan başlamaları gerektiği söylenmiştir. Ayrıca göçle gelen öğrencilerin uygun yönde başlamalarını sağlamak için satır başlarına da gülen yüz yapıştırılmıştır. Verilen etkinliği doğru hareketlerle ve taşırmadan yapan öğrenciler ödüllendirilmiş ve yaptıkları etkinlikleri panoda istedikleri yere asabilecekleri söylenmiştir. Süreci daha eğlenceli hale getirmek için ay şeklinde olan kurabiyelerden faydalanılmıştır. Y harfini daha iyi kavratmak ve öğrenmede kalıcılığı sağlamak için üzerinde y harfi yazılı olan ve hilal şeklinde hazırlanan kurabiyeler sınıfa getirilmiş ve motive etmek amacıyla dağıtılmıştır.

Süreç boyunca neredeyse her gün 20'şer dakika akran işbirliği çalışmalarına yer verilmiştir. Ders esnasında Zeynep kod adlı öğrenci ile öğretmen arasında gerçekleşen diyalog şöyledir:

Öğretmen: Çok beğendim. Harika olmuş. Gülen yüzü beraber yapıştıralım mı?

Zeynep: Olur (gülerek)

Öğretmen: Şimdi sana bir görev daha vereceğim. Ahmet'in yanına otur. Taşırırsa sen sil ve daha güzel yazabileceğini söyle. Belki sen yanındayken daha güzel ve daha hızlı yazar. Olur mu?

Zeynep: Tamam öğretmenim.

Öğretmen: Ahmet'in çalışması bittiğinde ikiniz birlikte çalışmalarınızı panoda istediğiniz yere asabilirsiniz.

Zeynep ve Ahmet öğretmenin yönergesini yerine getirmişlerdir. Gün sonunda öğretmen yaşanan süreci yansitıcı günlükte şöyle ifade etmiştir:

Akran işbirliği çalışmalarına daha fazla yer vermeliyim. Öğrencilerin birlikte çalışmaları, daha özenli yazmalarını destekliyor. Daha iyi odaklanmalarını sağlıyor ve sıkılmalarını engelliyor. Ortak çalışma yapmanın mutluluğu yüzlerinden okunuyor. Bu durum sevindirici... (Yansıtıcı günlük 18.12.2017)

Yazma süreci ile ilgili bulgular incelendiğinde öğrencilerin harfi çizgiye konumlandırmada ve harfin boyutunu ayarlamada sorun yaşadıkları görülmüştür. Öğrenciler birinci grup sesler bittiğinde harfleri çizgiye konumlandırmada ve boyutunu ayarlamakta zorluk yaşamalarına rağmen üçüncü grup harfler bittiğinde sürece adapte olmuşlardır. Yazma aşamasında boyunca en çok e, a ve yharflerini yazarken zorlandıkları tespit edilmiştir. Öğretmen kelimeler arasında gereğinden fazla boşluk bırakan öğrenciler için parmak ile boşluk bırakmaları gerektiğini uygulayarak göstermiştir. Değerlendirme etkinliğinde harfin geçtiği kelimeleri bulma çalışması yapılmıştır. 
Örneğin " $y$ " harfinin değerlendirme etkinliğinde öğrencilere, içinde "Y" ve "y" harfinin geçtiği çeşitli kelimeler verilmiştir. Öğrencilerden küçük "y" harfinin geçtiği kelime kutularını pembeye, büyük "Y" harfinin geçtiği kelime kutularını açık maviye boyamaları istenmiştir. "Y" ve "y" harflerinin bulunmadığı kutuları ise boyatmamaları konusunda uyarıda bulunulmuştur. Bir sonraki derste kelimelerin içindeki " $y$ " harflerini saymaları ve kelime kutucuklarının altlarındaki noktalı yere kelimede geçen " $y$ " harfinin sayısını yazmaları söylenmiştir. Süreç boyunca sesi yazma, okumadan çok daha yavaş öğrenilmiştir. Dolayısıyla dikte çalışmalarında aile ilgisizliğinden dolayı okuma ve yazmanın eş zamanlı olarak öğretilmesinde zorluk yaşanmıştır.

\section{Hece öğretimine ilişkin bulgular}

Hece oluşturma aşamasında öğretmen harfi yazmış ve öğrencilerden okumalarını istemiştir. Sonra yazılı harfin yanına bir başka harf (farklı renk tebeşirle) yazarak okumalarını istemiştir. Daha sonra iki harfi birleştirirsek nasıl okunur? Diye sınıfa sormuştur? Öğrencileri cesaretlendirerek tahtada yazılı heceyi okumalarını sağlamıştır. Akabinde heceyi kendisi okumuş ve öğrencilerinin tekrar etmesini istemiştir. En sonunda da yeni oluşan heceyi tüm sınıf birlikte okumuştur. Bu süreçte yaşanan sorunlardan biri öğrencilerin "le" hecesini "el" diye okumalarıdır. Sorunu aşmak ve öğrencilerin ilk grup harflerde açık heceleri okumada zorlanmalarını engellemek için ritimle okuma çalışmaları yapılmıştır. Örneğin ki hecesinin okunması esnasında öğretmen ve öğrenciler arasında gerçekleşen diyalog şöyle îzah edilebilir:

Öğretmen: Şimdi yeni bir hece öğreneceğiz. Beni dikkatle dinlemenizi ve sorduğum sorulara cevap vermenizi istiyorum. Elimdeki harfin adı ne?

Öğrenciler: k (Hep birlikte)

Öğretmen: Peki bu harfin adı ne (Diğer eliyle “i” harfinin bulunduğu kartı göstererek)

Öğrenciler: iiiii

Öğretmen: Şimdi bu iki harfi birleştiriyorum. Şimdi okuyalım.

(Öğrencilerden bazıları "ki" diyerek doğru okurken bazıları "ik" diyor, bazıları da sessiz kalıyor.

Öğretmen: O halde beni dikkatle dinleyin. Bir eliyle " $k$ " diğer eliyle " $i "$ harfinin bulunduğu kartları sırayla göstererek eş zamanlı olarak ritimle "k" "i", "k" "i", "k" "i", "ki". "ki", "ki", "ki". "ki" der ve öğrencilerin aynı diyalog ve aynı ritimle "ki" hecesini seslendirmelerini ister. Öğretmen model olarak birkaç kez gösterdikten sonra öğrencilerin aynı ritimle heceleri öğretmen desteği olmaksızın okudukları tespit edilmiştir. Daha sonra "ki" hecesini defterlerine bir okuyup bir yazmaları isteniştir. Yazı sürecinin sıkıcı hale gelmesini engellemek için sadece beş satır yazmaları istenmiştir. En sonunda da yapılan çalışma öğretmen tarafından kontrol edilmiştir. Öğrencilerle birlikte oluşturulan hece kartlarından sıklıkla yararlanılması ve hece tablosu, hece öğretimi sürecini kolaylaştırmıştır. Ayrıca okumada zorlanılan hecelerin kavratılmasında görsel ve işitsel materyallerden yararlanılmış ve okuyuşa vurgu yapılmıştır.

\section{İlk Okuma Yazma Sürecinde Kelime ve Cümle Öğretimine İlişkin Bulgular}

Öğretilen her yeni sesi daha önce öğrenilenlerle ilişkilendirmek için yeni heceler ve hecelerden yeni kelimeler oluşturulmuştur. Bazen oluşturulan kelimelerden cümleler oluşturulmuş bu etkinlik bütün sınıfın katılımıyla gerçekleştirilmiştir. Bazen de çeşitli kelimeler verilmiş ve verilen kelimelerden anlamlı cümleler kurmaları istenmiştir. Öğrenciler Kaya, Rana, Mina gibi bildikleri isimleri ifade eden kelimeleri daha rahat okurken ve yazarken; kalk, kesk, sert gibi iki ünsüzün yan yana geldiği kelimeleri okumakta ve yazmakta zorlanmışlardır.

Üretilen heceler çoğaldıkça öğrencilerin kelime ve cümleleri daha kolay oluşturdukları gözlenmiştir. Kelime öğretiminde sınıftaki öğrencilerin isimlerinden sıklıkla yararlanılmıştır. Harfler ve heceler öğrenildikçe oluşturulan hecelerden öğrenci isimlerine ulaşılmış ve ismi 
okunabilen her öğrencinin ismi, fotoğrafiyla birlikte sınıfta panoya asılmıştır. Heceler öğrenildikçe adını ve soyadını yazılabilen her öğrencinin adı ve soyadı, fotoğrafinın altına yazılmıştır. Bu bağlamda öğrenciler isimlerin ilk harflerinin büyük, soyadlarının ise tüm harflerinin büyük yazılması konusunda farkındalık kazanmışlardır.

Anlama becerilerini geliştirmek için somut kelimelerden cümleler oluşturulmaya çalış1lmıştır. Süreç boyunca öğrenciler kelime ve cümle üretmeleri konusunda cesaretlendirilmeye çalışılmıştır. Süreci daha eğlenceli hale getirebilmek için oyunla öğretim uygulamalarına yer verilmiştir. Örneğin sınıf iki gruba ayrılmış, öğrenciler ikişerli olarak eşleştirilerek sıralanmıştır. Belirlenen sürede yansıda gösterilen dört farklı kelimeyi kullanarak doğru cümle yazanher öğrenci kendi grubuna bir puan kazandırmıştır. Dört temel dil becerisi olan konuşma, dinleme, okuma, yazma becerileri bu süreçte eş zamanlı olarak geliştirilmeye çalışılmıştır. Dinleme becerisini geliştirmek için bazen videolar izlettirilmiş, masallar anlatılmış, hikayeler okunmuştur. Daha sonra düşündükleri üzerine konuşmaları sağlanmış ve akıllarında kalanı defterlerine yazmaları istenmiştir. Öğrenciler anlamını bilmedikleri kelimeleri küçük kartlara yazmışlardır. Kartın arkasına kelimenin anlamını ve kelimenin cümle içinde kullanılışını ifade eden bir cümle yazarak bilinmeyen kelimelerin öğretimi gerçekleştirilmiştir.

\section{Metin Oluşturma Sürecine İlişkin Bulgular}

Metin oluşturma sürecinde genellikle oyunla öğretim uygulamalarına yönelik etkinlikler düzenlenmiştir. Örneğin "Haydi Meydana" adlı bir oyun oluşturulmuş ve süreç boyunca haftada en az üç kez tüm sınıfın katılımıyla oynanmıştır. Öğrenciler üçlü gruplar halinde eşleştirilmiş ve yansıda bir cümleyi oluşturan 4-5 kelime karışık sıralama ile verilmiştir. Öğrencilerden yansıda görülen kelimeleri okuyup kurallı cümle haline getirmeleri istenmiştir. Cümleyi doğru kuran her öğrenci kendi grubuna bir yıldız kazandırmıştır. Süreç boyunca yapılan etkinliklerin öğrencilerin ilgisini çektiği ve daha mutlu ders işlemelerini desteklediği tespit edilmiştir.

\section{Metin Okuma Sürecine İlişsin Bulgular}

Öğretmen, metin okuma sürecinde öncelikle metinlerde yer alan görseller hakkında öğrencilerle sohbet etmiştir. Metnin konusunu tahmin etmeleri için metnin görsellerinden yararlanmıştır. Sohbet esnasında çocuklara metinde geçen anahtar kelimeleri kullanmalarına yönelik sorular sormuştur. Daha sonra okuma amacı belirlenmiş ve metni öğrencilerin yumuşak bir ses tonuyla okumaları istenmiştir. Öğrenciler, metni birkaç kez okuduktan sonra öğretmen öğrencilere model olacak şekilde kendi okumuştur. Bu süreçte yankılayıcı okuma, koro okuma ve eşli okuma stratejilerinden faydalanılmıştır.

Yankılayıcı Okuma: Akıcı okumayı geliştiren yöntemlerden biridir (Carbo, 1996; Moskal \& Keneman, 2011). Nasıl okunması gerektiği hakkında farkındalık yaratır (Güneş, 2007; Kato, 2012). Stratejinin uygulanması sürecinde öğretmen; kelime, kelime grupları ya da cümleleri yüksek sesle bir seferde okumuştur. Öğretmenin okumasından hemen sonra öğrenciler tekrar etmiştir. Öğrencilerin hata yaptığı ya da takıldığı ifadeleri öğretmen tekrar okumuş ve öğrenciler doğru okuyana kadar bu döngü devam etmiştir. Bu süreçte öğrencilerin metni gerçekten takip ettiğinden emin olmak için ayrıca öğrencilerin metni okumayıp, sadece duyduklarını tekrar etmelerinin önüne geçmek için kalemle takip etmeleri sağlanmıştır. Süreç içerisinde göçle gelen öğrencilerin okuduklarını anlayabildiği ve programı takip edebildiği tespit edilmiştir.

Koro Okuma: Birden fazla okuyucunun metni aynı anda, hep birlikte ve yüksek sesle okuması olarak ifade edilir. Koro okuma yöntemi ile gerçekleştirilen uygulamalarda öğrencilerin hata yapmak korkusuyla değil iyi okuyucuyu örnek alma çabasıla metni doğru okumaya çalıştıkları gözlenmiştir.

Eşli Okuma: Akıcı okuyan biri ile ondan daha zayıf okuyan birinin eşleştirilerek aynı metni okumalarının sağlandığı bir öğretim tekniğidir (Mathes, Fuchs, Fuchs, Henley \& Sanders, 
1994; Topping, 1989). Akıcı okuyan öğrenci, akabinde de zayıf okuyucu metni okur. Böylece akıcı okuyan öğrenciyi zayıf okuyucu model alır. Zayıf okuyucu, sıra kendisine geldiğinde iyi okuyucuyu model alarak ve prozodiye dikkat ederek okumaya çalışır (Mathes, Fuchs, Fuchs, Henley \& Sanders, 1994). Uygulaması kolay olan bu yöntemin sözcük dağacığını zenginleştirdiği, akıcılığı ve anlamayı geliştirdiği ayrıca öğrencileri okumaya motive ettiği ifade edilebilir.

\section{Okuma-Yazma Öğretim Sürecinde Yaşanan Sorunlara İlişkin Bulgular}

Yaşanan sorunlara ilişkin bulgular; materyal kaynaklı, öğrenci kaynaklı, sistem kaynaklı ve veli kaynaklı bulgular başlıkları altında izâh edilmiştir.

\section{Materyal Kaynaklı Sorunlara İlişkin Bulgular}

Araştırmada yaşanan sorunların ilki devlet kitaplarının sahip oldukları nitelikler bakımından okuma yazma öğretimi için yeterli olmamasıdır. Kitaplar öğrencilerin harfleri seslendirmeleri için anlamsız kelimelerden oluşturulmuştur. Anlamsız kelimelerden anlamsız dörtlükler oluşturulması, öğrencilerin okuma motivasyonunu olumsuz yönde etkilemiştir. Kitapta yer alan dörtlüklerde, tümceler arası ilişki kurulmadığı görülmüşsür.

Devlet Kitab1

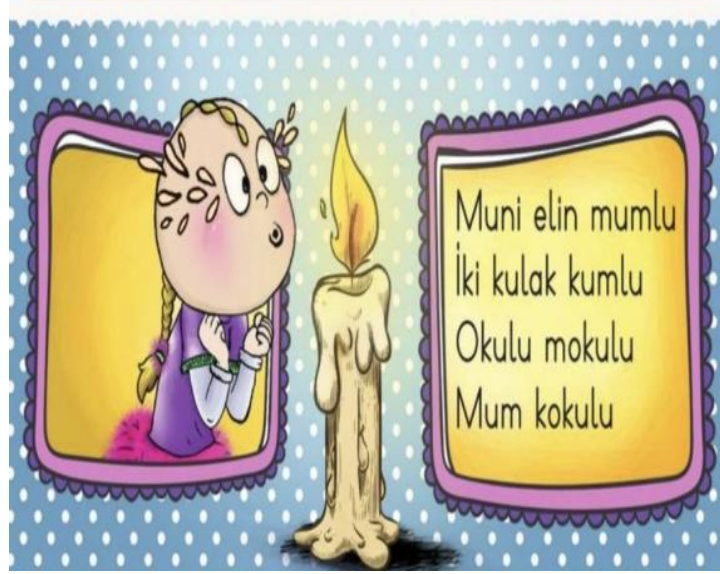

Olması Düşünülen

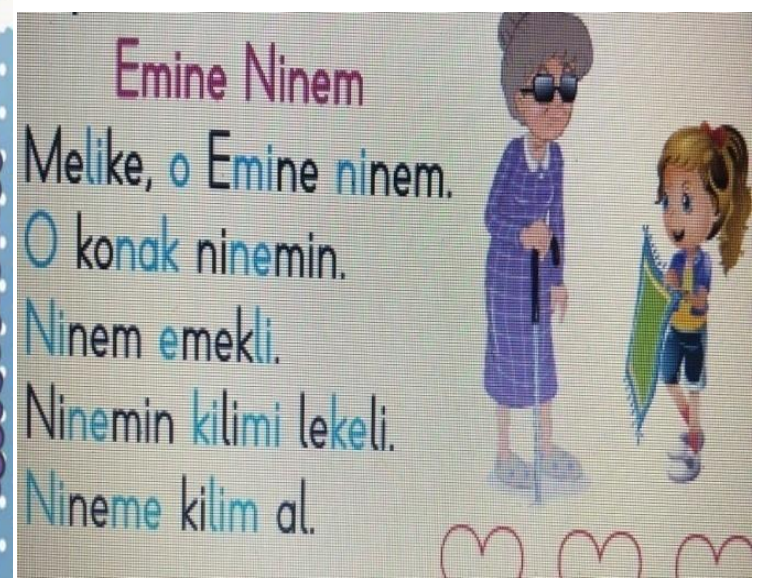

Yukarıdaki resimde görüldüğü gibi dörtlükler harflerin tekrarlanmasına yöneliktir. Okuma yazma öğretimi ile ilgili kitapta görsel-metin ilişkisinin yeterince iyi kurulmadığı, daha kaliteli basımla, çocuğun dünyasına daha uygun çizimlerle ve daha estetik olacak biçimde kısacası daha nitelikli hazırlanması gerektiği tespit edilmiştir.

Okunabilirlik açısından incelendiğinde, kitapta yer alan dörtlüklerin anlamsız sözcüklerden oluştuğu bu durumun okuma akıcıllğını olumsuz yönde etkilediği belirlenmiştir. İçerikle ilgili olarak kitapta yer alan birçok sözcüğün Türkçe karşıllığının olmadığı görülmüştür.

Ders kitabı yeterlilik yönünden incelendiğinde çocukların okuma-yazmayı öğrenebilmeleri için ses, hece, kelime ve cümleleri içeren daha çok etkinliğe gereksinim olduğu dolayısıyla kitabın yeterli olmadığı tespit edilmiştir. Sonuç olarak İlkokul 1. Sınıf Okuma-Yazma Öğreniyorum Kitabının işlevsel bir biçimde hazırlanmadığı ortaya konmuştur.

Ders kitaplarında yer alan metinler incelendiğinde, metin sayısının çocuğun akıcı okumasını sağlayacak kadar yeterli olmadığı görülmüsstür. Okuma yazma öğretim süreci boyunca çocukların daha akıcı olmasını sağlamak için ders dışı kaynaklardan yardım alınmıştır.

\section{Veli Kaynaklı Sorunlara İlişkin Bulgular}

Araştırma sosyo-ekonomik olarak dezavantajlı bir çevrede yaşayan çocuklarla gerçekleştirilmiştir. Öğrencilerin okuma-yazma becerilerini edinmede zorlanmalarının bir nedeni 
de veli katkısının ve evde çalışma ortamının olmamasıdır. Ayrıca sınıfta göçle gelen çocuklar vardır. Göçle gelen çocukların ev içerisinde birçok sorumluluk üstlendiği görülmüştür. İlk okuma yazma süreci boyunca okul öncesi eğitim almamış öğrenciler ve göçle gelen öğrencilerle birebir ilgilenilmiştir. $\mathrm{Bu}$ durum araştırmacının zaman yetersizliği yaşamasına ve eğitim kalitesinin düşmesine neden olmuştur.

Genel olarak göçle gelen öğrencilerin okuma yazma öğretim sürecinin tüm aşamalarında zorlandıkları tespit edilmiştir. Benzer şekilde Sarı'nın (2001) çalışmasında da iki dilli çocukların cümle çözümleme yöntemi ile okuma yazma öğrenirken hazırlık, cümle, kelime, hece, ses ve serbest okuma yazma devrelerinde ana dili Türkçe olan çocuklara göre daha fazla sorun yaşadıkları ve bu sorunları daha uzun sürede aşabildikleri belirlenmiştir. Araştırmanın gerçekleştirildiği okulda öğretmenler göçle gelen bazı öğrencileri akranlarına yetiştirmek için kurs açtıklarını ve her gün iki buçuk saat erken geldiklerini belirtmişlerdir. Buna rağmen dil bilmeyen öğrencilere okuma yazma öğretim sürecinin okul kapsamında da genel olarak başarılı olmadığı belirlenmiştir.

Göçle gelen öğrencilerin bazılarının okula geç geldiği, yeterli beslenme ile gelmediği veya beslenme getirmediği tespit edilmiştir. Bu durum çocukların akademik başarılarını olumsuz yönde etkilemiştir. Yaşanan sorun yansıtıcı günlükte aşağıda belirtildiği gibi izâh edilmiştir.

"Genellikle geç geliyor. Beslenme getirmediği zamanlarda evde de yemek yemediğini söylüyor. Henüz çok küçük olumsuz duygular yaşamasını engellemek istiyorum ve bazen yetersiz kaldığımı hissettiğim zamanlar oluyor. Belki PICTES projesi kapsamında özel durumu olan bazı çocuklar için okul kantinleri ile anlaşılarak öğrencilerin aç kalması önlenebilir. (Yansıtıcı günlük 15.12.2017)

Sürecin başında bazı veliler arasında sosyal nefret sorunlarının yaşandığı gözlenmiş bu sorunların üstesinden gelebilmek için hafta sonu 8 kişilik veli grubu ile yaratıcı drama faaliyetleri gerçekleştirilmiştir. Yapılan etkinlikler sonucunda velilerin göçle gelenlere yönelik daha olumlu tutum geliştirmeleri sağlanmıştır.

\section{Sistem Kaynaklı Sorunlara İlişkin Bulgular}

Anadili farklı olan ve göçle geldiği tespit edilen iki öğrencide öğrenme güçlüğü tespit edilmiştir. Ayşe adlı öğrenci ikinci dönemin sonlarına doğru okuma ve yazma becerisini yoğun bir çaba sonucu kazanırken Ahmet adlı öğrenci defalarca ve defalarca tekrara rağmen bellek problemleri yaşamıştır. Dolayısıyla Rehberlik Araştırma Merkezine yönlendirilmek istenmiştir. Rehberlik araştırma merkezinde öğrenci zeka testine tabi tutulamadığından ses farkındalı̆̆ alfabetik ilişkileri kavrama ve okuma becerisinde ilerleme gösteremeyişinin nedenleri tespit edilememiştir. Süreç boyunca öğrencinin rehberlik araştırma merkezinden destek alması mümkün olmamıştır. Yaşanan bu durum sistem kaynaklı bir sorun olarak kayda geçmiştir.

\section{Öğrenci Kaynakı Sorunlaraİlişkin Bulgular}

Okuma yazma öğretim süreci boyunca bazı öğrencilerde arkadaşlarına şiddet uygulama, okul ve sınıf eşyalarına zarar verme gibi sorunlar yaşanmıştır. Sorunların üstesinden gelebilmek için "akran zorbalığı" konulu atölye çalışmaları yapılmıştır. Gerçekleştirilen atölyeler sonucu tek bir öğrenci hariç tüm sınıfta şiddet eğilimlerinin azaldığı tespit edilmiştir. Şiddet eğilimli olan öğrencinin çocuk psikoloğuna görünmesi sağlanmıştır. Anne ve babasının ayrı olmasından dolayı depresyon yaşadığı belirlenen öğrenci ile yıl boyunca özel olarak ilgilenilmiştir. Bu zorlu sürecin sadece öğrenciyi değil tüm sınıfi olumsuz yönde etkilediği izâh edilebilir.

Araştırmada öğrenci kaynaklı sorunlardan bir diğeri göçle gelen çocukların arkadaş ortamında ve evde, Türkçeye dilinde film bile izlememeleri ve sadece kendi anadillerini konuşmalarıdır. Çocuklar Türkçe'yi yeterince bilmedikleri için kesik kesik cümleler kuruyorlar. Örneğin "Derse geç kaldım, özür dilerim" demesini bekliyorum. Defalarca bu cümle üzerine prova yapmamıza rağmen yine de; 'Ben... özür' diyor.” Dil sorununu çözmek için her gün düzenli olarak 
birkaç cümlenin üzerinde tekrarlarla çalıştık, bu esnada drama yaptık. Baktım çok yavaş ilerliyoruz velilerimi sürece dâhil ederek ders dışı saatler için bir etkinlik geliştirdim. "Annemin öğretmeniyim" etkinliği ile her gün okulda öğrendikleri beş cümleyi annelerine öğretmelerini istedim. Yaşanan sürecin öğrencilerin ve velilerin dil öğrenme sürecine olumlu katkılar sağladığı söylenebilir.

\section{Sonuç ve Tartışma}

Göçle gelen çocuklara okuma yazma öğretiminde en önemli problem dildir. Dil becerilerinin yetersizliği nedeniyle öğrenciler okuma yazma programını takip etmede zorluk yaşamaktadırlar. Alanyazında yapılan çalışmalar bu bulguyu destekler niteliktedir. Çalışmalarda göçle gelen çocuklar dil becerilerinin yetersizliği nedeniyle kendilerini ifade etme, okuma, yazma, anlama ve anlatmada güçlük çekerler (Tamer, 2017; Kultas, 2017, Özdemir, 2016; Gazeller 2014; Erdem, 2017; Sarıtaş, Şahin ve Çatalbaş, 2016; Akalın, 2016).

Birinci grup seslerde Öğrencilerin harfi çizgiye konumlandırmada ve harfin boyutunu ayarlamada sorun yaşadıkları tespit edilirken ikinci grup seslerde daha başarılı olmuşlardır. Öğrencilerin okuma yazma öğretim süreci boyunca en çok e, a ve y harflerini yazarken zorlandıkları tespit edilmiştir.

-Öğrenme öğretme süreci devam ettikçe hece oluşturma çalışmalarında olumlu gelişmeler görülmüştür. Birinci grup seslerde öğrenciler heceleri oluşturmakta ve okumakta zorlansa da ikinci grup seslerde en fazla iki sesten oluşan iki heceli kelimeleri okumada daha başarılı olmuşlardır.

- Devlet tarafından hazırlanan okuma-yazma öğreniyorum kitaplarının nitelik ve nicelik olarak yeterli olmadığı sonucuna ulaşılmıştır. Kitaptaki metinlerde anlatım bozukluklarının olması, zorlama ve uydurma sözcüklere yer verilmesi, tümceler-görseller arasında tutarsızlıkların olması okuma yazma öğretim sürecini ve Türkçe öğretimi olumsuz yönde etkilemiştir. Akyol (2003) ilkokul birinci sınıfta metin içi anlam kurmaya ağırlık verilmesi gerektiğini, bunu metin dışı ve metinler arası anlam kurmanın izlemesi gerektiğini belirtmektedir. Bu durum; ders kitaplarının revize edilmediği sürece çocuklarda dil öğrenme becerisinin ve metin içi anlam kurma sürecinin olumsuz etkileneceğini göstermektedir.

- Özellikle ana dili farklı olan ve göçle geldiği tespit edilen öğrenciler okul kültürüne uyum sağlamakta zorlanmışlardır. Öğretmenlerin, dil problemi sebebiyle zorluklar yaşayan Suriyeli öğrencilerin öğrenmesini kolaylaştırmak için görsel araçlar, akranla öğrenme ve grupla öğretim tekniklerinin göçle gelen öğrencilerin okuma yazmayı öğrenmesinde etkili olduğu sonucuna ulaşılmıştır.

- Ritimle yapılan tekrarlarla öğrencilerin açık heceyi kavrama sorunlarının aşıldığı tespit edilmiştir. Özellikle açık heceleri ritimle okumanın kavramayı kolaylaştırdığı sonucuna ulaşılmıştır.

- Okul öncesi eğitim almamış öğrencilerin genel olarak harfin boyutunu sayfa yüzeyinde belirlenen satıra yerleştiremedikleri, harfleri belirlenen yükseklik ve genişlikte yazma konusunda zorlandıkları kelimeler arası boşlukta ise zorlanmadıkları tespit edilmiştir.

-Öğrencilerin kavramakta en çok zorlandıkları harflerin “y, p, 乌̆” olduğu tespit edilmiştir. Yazma sürecinde ise en çok e, a, y harflerini yazmakta zorlandıkları harflerin kuyruklarını konumlandırmada sorun yaşadıkları, yarım bıraktıkları ve uygun formda konumlandıramadıkları tespit edilmiştir. Ayrıca iki sessiz harfin yan yana kullanıldığ 1 "alla, telle" vb. sözcükleri okuyup yazmada güçlükler yaşadıkları gözlenmiştir. Türkçe dil becerilerindeki yetersizlikten dolayı göçle gelen öğrencilerin okuduklarını anlamada zorlandıkları tespit edilmiştir. Öğrenme sürecini kolaylaştırmak için görsel araçlar, akranla öğrenme ve grupla öğretim tekniklerinin göçle gelen öğrencilerin okuma yazmayı öğrenmesinde etkili olduğu sonucuna ulaşılmıştır. 
-Harf-ses ilişkisine yeterince dikkat edemeyen öğrenciler okumaları esnasında yazılı kelimeye benzer farklı kelimeler okumuşlardır (konak yerine konuk gibi),

-Orta heceleri üç harften oluşan kelimelerin, orta hecelerinin son harfini yutma hataları gözlenmiştir. (sarımsak-sarısak, Erzincan-Erzican, ... vs.)

-Dikkat süresi yeterince uzun olmayan ve odaklanma problemi yaşayan öğrenciler metnin ilk cümlelerini doğru, sonraki cümleleri ise hatalar yaparak okumuşlardır.

-Çok heceli kelimeleri okurken duraksama, sıkılma ve okuyamama davranışları gözlenmiştir. (örneğin "Kastamonu" kelimesini oluşturan her bir heceyi ayrı ayrı okuyabilme ancak kelimenin tümünü okumakta zorlanma, son heceye gelinceye kadar ilk heceleri unutma, bu döngüsel süreçte dikkatini yoğunlaştıramadığı için sıkılma davranışları sergileme)

-Göçle gelen öğrencilerde anadil farklılı̆̆ından dolayı kelimeleri zihinde kodlamak için düşünme, bu düşünsel süreçte de kelimenin başına ses veya ses bileşimleri ekleme bu bağlamda kelimeyi doğru telafuz edememe (kalem-ekalem, İskenderun-eîilskenderun) gibi okuma hatalarına rastlanmıştır.

- Göçle gelen bazı öğrencilerin derse geç geldiği, okul ve sınıf kurallarına uymadığı belirlenmiştir. $\mathrm{Bu}$ sonuç Sarıtaş ve diğerleri (2016) nin çalışmasıyla benzerlik göstermemektedir. Sarıtaş ve diğerleri, göçle gelen öğrencilerin sınıf ve okul kurallarına uymama, derse ilgisizlik, sorumluluklarını yerine getirmeme gibi sorunlar yaşadıklarını belirtmişlerdir. Diğer yandan Özdemir (2016) ve Gibson (1987) araştırmaları benzer sonuçlar göstermemiştir. Özdemir ve Gibson, göçle gelen öğrencilerin okulun ilk dönemlerinde derse geç geldiklerini, nadiren okula gelmediklerini ve disiplin problemlerinin az olduğunu ifade etmişlerdir.

- Okul öncesi eğitim almayan ve öğrenim hayatlarında ailelerinden destek alamayan iki dilli öğrencilerin okumayı öğrenmede güçlük yaşadıkları tespit edilmiştir. Bu durum akademik yetersizlik, olumsuz benlik algısı ve düşük özgüvene neden olmuştur. Nitekim Akyol (2011: 42) öğrencilerin bedensel ve zihinsel gelişimlerinin farklı olabileceğini dolayısıyla gelişimi yeterli olmayan öğrencilerin okula kayıt edilemeyebileceğini îzah etmiştir. Araştırmada ulaşılan bu sonuç Akyol (2011) tarafindan belirtilen bu durumu desteklemektedir.

- Göçle gelen öğrencilerin okuma yazma becerisini kazansalar bile anladıklarını ifade etmede zorlandıkları ve konuşurken düzgün cümle kuramadıkları belirlenmiştir. Ayrıca anladıklarını düzeylerine uygun bir anlatım tarzıyla ifade edemedikleri sonucuna ulaşılmışıı

\section{Öneriler}

- Milli eğitim bakanlığı ana dili farklı olan öğrencilere sesli harf kartları ve sesli hikâye kitapları verebilir. Bu bağlamda okuma-yazma öğrenim sürecine katkıda bulunabilir.

- Veli-öğretmen ilişkilerinin güçlendirilmesine yönelik seminerlerin verilmesi sağlanabilir. Bu bağlamda velilerin süreçte daha etkin olmaları sağlanabilir.

- Devlet tarafından hazırlanan okuma-yazma öğreniyorum kitaplarının, daha kaliteli çizimlerle, daha somut kelimelerle, kelimelere daha uygun olan ve daha estetik hazırlanan görsel figürlerle kısacası çocuğa görelik ve anlatım figürleri açısından daha nitelikli ve donanımlı hazırlanması sağlanabilir

- Okuma yazma setinin velilere aldırılması MEB tarafından yasaklanmıştır. Öğretmenlerin yaşadığı bu sorun yasağın kaldırılmasıyla çözülebilir.

- Öğretmenler öğrencilerine görsel ağırlıklı kelime oyunları oynatabilir.

-"Okuma Yazma Öğreniyorum" kitabında yer alan metinlerin anlam yönünden tutarlı kelimeler ve kelimeleri daha iyi destekleyen görsellerle hazırlanması sağlanabilir. 
- PISA (2016) verileri bağlamında ülkemizin okuma ortalamaları bakımından OECD ülkelerinin gerisinde kaldığı (Son sıralarda yer aldığı) belirlenmiştir. Bu durum okuma eğitimine daha fazla önem verilmesi gerektiğini açıkça göstermektedir. Dolayısıyla okul öncesi eğitim almamış anadili farklı öğrencilerin okula başlama yaşının, hiçbir öğrenim hayatları olmamış ebeveynlerine bırakılması sağlıklı bir karar olarak görülmemektedir. Bu bağlamda yasal düzenlemelerin getirilmesi, çocuğun okula başlama yaşının psikolojik danışman, aile, sınıf öğretmeni ve çocuk psikiyatrlarının vereceği ortak kararla belirlenmesi gerekliliği bir ihtiyaç ve öneri olarak görülmektedir.

- İngiltere, Galler, İskoçya ve Hollanda gibi gelişmiş ülkelerde çocukların 5 yaşında okula başladıkları belirtilmektedir (EURYDICE, 2012). Ancak bu ülkelerde okul öncesi eğitimin ülkemize göre çok daha yaygın olduğu ve okulların nitelik olarak daha donanımlı olduğu bilinmektedir. Ülkemiz için sağlıklı ve nitelikli bir eğitimin bize göre daha gelişmiş ülkeleri taklit ederek değil; ülke gerçeklerini göz ardı ederek tavandan tabana değil, koşullar ve şartlar bağlamında tabandan tavana doğru bilinçli uygulamalarla geliştirilebileceği düşünülmektedir. $\mathrm{Bu}$ bağlamda göçle gelen öğrenciler için ayrı bir program hazırlanması önerilebilir. Okul öncesi dönemde dil becerilerini geliştirmek için 3 yaşından itibaren ilk dönem yarım saat-bir saat arası, ikinci dönem 1-1.5 saat, üçüncü dönem 1.5-2 saat, dördüncü dönem 2-3 saat, sonraki yıl ise diğer öğrenciler gibi tam zamanlı okul öncesi eğitim almaları dilimizi çok daha kolay öğrenmelerini ve ilkokula daha mutlu başlamalarını sağlayabilir.

- ABD, İngiltere, Belçika gibi gelişmiş ülkelerde okuma güçlügü yaşayan öğrenciler için okuma uzmanları vardır. Okuma uzmanı olarak adlandırılan eğitimciler okuma güçlüğü yaşayan her bir çocuk için özel bir program uygulamaktadırlar.

- Göçle gelen öğrencilerin okula yeterli beslenme ile gelmediği tespit edilmiştir. Bu durumun akademik başarılarını olumsuz yönde etkilediği söylenebilir. Maddi durumu yetersiz çocuklar için Pictes kapsamında okul kantinleri ile görüşülüp beslenmeleri sağlanabilir.

- Öğretmenlere iki dilli çocukların akademik sorunlarını gidermeye yönelik platformlar kurulup deneyimler aktarılabilir. Velilere ve öğrencilere yönelik konferanslar verilebilir. Eğitim koçluğu, akran zorbalığı temalı atölye çalışmaları, yaratıcı drama faaliyetleri gerçekleştirilebilir. Velilere yönelik yaratıcı drama faaliyetleri gerçekleştirilerek göçle gelenlere yönelik daha olumlu tutum geliştirmeleri sağlanabilir.

- Göçle gelen bazı öğrencilerdeki öğrenme güçlüklerini tespit etmeye yönelik olarak leiter zekâ testi uygulanabilir. Psikolojik danışmanlar ve özel sektörlerden sertifika almış kişiler bu testi uygulayabilir. Ancak RAM da rehberlik öğretmenleri dilimizi bilmeyen öğrencilere yönelik herhangi bir tespit yapamıoorlar. Leiter zekâ testi, dile dayalı bir zeka testi olmadığından dolayı Arapça öğretmenleri, testin uygulanmasına yönelik iki-üç aylık eğitim aldıktan sonra testi, Rehber Psikolojik Danışman ile birlikte uygulayabilir. Bu amaçla ayda, iki-üç gün Arapça öğretmenleri RAM da görevlendirilebilir. Görevlendirildikleri süre içinde Rehberlik Araştırma Merkezlerinde göçle gelen çocuklara yardım edebilirler.

- Göçle gelen velilerin isteği ve imzalı onayı ile pictes kapsamında çocukların okul öncesi eğitim almaları (mümkünse iki yıl) sağlanabilir. Çocuklar bu süreçte hem el kaslarını geliştirebilirler, toplum kurallarına uygun yemek yeme kültürünü, temizlik alışkanlıklarını kazanabilirler. Bu süreç dil becerilerinin geliştirilmesine katk1 sağlayabilir. Böylece okula diğer arkadaşları gibi daha mutlu başlayabilirler.

\section{Kaynakça}

Akalın, A. (2016). Türkiye’ye gelen Suriyeli göçmen çocukların eğitim sorunları (Yayımlanmamış yüksek lisans tezi). İstanbul Aydın Üniversitesi Sosyal Bilimler Enstitüsü. 
Akyol, H. (2003). Metinlerden anlam kurma. Türklük Bilimi Araştırmaları,13(13), 49-58.

Akyol, H. (2011). Yeni programa uygun Türkçe öğretim yöntemleri (4.Baskı), Pegem Akademi Yayincilik.

Aykırı, K. (2017). Sınıf öğretmenlerinin sınıflarındaki Suriyeli öğrencilerin eğitim durumlarına ilişkin görüşleri. TurkishJournal of PrimaryEducation, 2(1), 44- 56.

Carbo, M. (1996). Selectingthe Right Reading Method. Teaching K-8 27, 1(84), 86-87.

Cin, G. (2018) Suriyeli öğrencilere eğitim veren sınıf öğretmenlerinin yaşadıkları sorunlar ve psikolojik sağlamlılık düzeyi: Adana ili örneği. Çağ Üniversitesi Sosyal Bilimler Enstitüsü.

Dorman, S. (2014). Educational needs assessment for urban Syrian refugees in Turkey.

Erdem, C. (2017). Sınıfında mülteci öğrenci bulunan sınıf öğretmenlerinin yaşadıkları öğretimsel sorunlar ve çözüme dair önerileri. Medeniyet Eğitim Araştırmaları Dergisi, 1(1), 26-42

Eurydice. (2012). Key Data on Education in Europe 2012. Brussels: Eurydice. http://eacea.ec.europa.eu/education/eurydice/documents/key_data_series/134EN.pdf

Gazeller, P. (2014). Göçe bağll olarak ilk ve ortaokullarda yaşanan sorunlara ilişkin yönetici görüşleri (Karabağlar örneği) (Yayımlanmamış yüksek lisans tezi). Okan Üniversitesi Sosyal Bilimler Enstitüsü.

Gibson, M. A. (1987). Theschoolperformance of immigrantminorities: A comparativeview. Anthropology\&EducationQuarterly, 18(4), 262- 275.doi:10.1525/aeq.1987.18.4.04x0018r

Gültutan S. (2019) Türkiye'de İlkokulda Öğrenim Gören Suriyeli Öğrencilerin Yazma Becerisine İlişkin Öğretmen Görüşleri. M.K.Ü Sosyal Bilimler Enstitüsü Yüksek Lisans Tezi.

Güneş, F. (2007). Türkçe öğretimi ve zihinsel yapılandırma. Nobel

Kato, S. (2012). Bridgingtheoryandpractice: Developinglower-levelskills in L2reading. The Language Learning Journal, 40 (2), 193-206.

Kultas, E.(2017). Türkiye'de bulunan eğitim çağındaki Suriyeli mültecilerin eğitimi sorunu (Van ili örneği) (Yayımlanmamış yüksek lisans tezi). Yüzüncü Yıl Üniversitesi Eğitim Bilimleri Enstitüsü.

Mathes, P. G., Fuchs, D., Fuchs, L. S., Henley, A. M., \&Sanders, A. (1994). Increasing strategic reading practice with Peabody class wide peer tutoring. Learning Disabilities Research and Practice, 9, 44-48.

McMillan, J. H. (2004). Educational research: Fundamentals for the consumers. MA: Pearson Education.

Merriam, S. B. (1998). Qualitative research and case study applications in education. Jossey-Bass.

Moskal, M. K., \&Keneman, A. F. (2011). Literacy leadership to support reading improvement: intervention programs and balance distruction. Guilford.

Özdemir, Ç. (2016). Sivas ilinde ögrrenim gören yabancı uyruklu öğrencilerin okul iklimine etkisine ilişskin görüşlerin incelenmesi(Yayımlanmamış yüksek lisans tezi). Cumhuriyet Üniversitesi Eğitim Bilimleri Enstitüsü.

Sarıtaş, E., Şahin, Ü.ve Çatalbaş, G. (2016). İlkokullarda yabancı uyruklu öğrencilerle karşılaşılan sorunlar. Pamukkale Üniversitesi Sosyal Bilimler Enstitüsü Dergisi, (Ek1), 208-229.

Tamer, M. G. (2017). Geçici koruma kapsamındaki Suriyeli çocukların Trabzon devlet okullarındaki durumu. Göç Dergisi, 4(2), 119-152. 